Article

\title{
Once Again, Nationality and Religion
}

\author{
Steven E. Grosby
}

Department of Philosophy and Religion, Clemson University, Clemson, SC 29634, USA; sgrosby@clemson.edu

Received: 22 July 2019; Accepted: 5 September 2019; Published: 8 September 2019

check for updates

\begin{abstract}
An examination of the relation between nationality and religion calls for comparative analysis. There is a variability of the relation over time and from one nation and religion to another. At times, nationality and religion have clearly converged; but there have also been times when they have diverged. Examination of this variability may lead to generalizations that can be achieved through comparison. While the generalizations achieved through a comparative analysis of the relation are heuristically useful, there are complications that qualify those generalizations. Moreover, while further refining the comparative framework of the relation between nationality and religion remains important, it is not the pressing theoretical problem. That problem is ascertaining what is distinctive of religion as a category of human thought and action such that it is distinguishable from nationality and, thus, a variable in the comparative analysis. It may be that determining that distinctiveness results in the need for a different framework to analyze the relation between nationality and religion.
\end{abstract}

Keywords: axial age; kinship; monolatry; monotheism; nation; priest; religion; territory

\section{Introduction}

Examination of the relation between nationality and religion calls for comparative analysis. It does so for two reasons: one, the variability of the relation over time and from one nation and religion to another; and two, the generalizations that may be achieved through the comparison. Over the years, I have several times turned my attention to clarifying the relation between nationality and religion, both through examining a particular expression of the relation, for example, ancient Israel and the worship of Yahweh (Grosby 2002) or nationality and the Catholic Church (Grosby 2016), and by providing a comparative framework (Grosby 2001, 2005, pp. 80-97). I shall again offer here a comparative analysis, but now with a different focus. While the generalizations achieved through a comparative analysis of the relation are heuristically useful, I shall concentrate on the complications that qualify those generalizations. Moreover, while further refining the comparative framework of the relation between nationality and religion remains important, it is not the pressing theoretical problem. That problem is ascertaining what is distinctive of religion as a category of human thought and action such that it is distinguishable from nationality and, thus, a variable in the comparative analysis.

\section{Territorial Kinship and Monolatry}

We begin with a historical episode that allows us to ascertain what is characteristic of the convergence of nationality and religion. For about one hundred and fifty years during the Early Dynastic Period of southern Mesopotamian history (2500-2350 BC), there was an ongoing war between the city-states of Lagash and Umma. One inscription describing this conflict reveals clearly the convergence between religion and the respective territorial kinships of these societies (Cooper 1986, pp. 54-57).

Enlil, the king (god) of all the lands, upon his firm command, drew the border between Ningirsu (god of Lagash) and Shara (god of Umma) ... Eannatum, ruler of Lagash ... made 
the border by extending the Inun-canal to Gu'edena (to the edge of the plain) ... At that boundary-channel he inscribed new boundary-stones ... If the man of Umma, in order to carry off fields (takes the fields or their produce by force), crosses the boundary-channel of (the god) Ningirsu (Lagash) ... be he an Ummaean or a foreigner, may Enlil destroy him!

Clearly observable from this inscription is the conception that the city-state Lagash has its own diety, Ningirsu, as does the city-state Umma, the deity Shara. Moreover, these deities have a demarcated territorial jurisdiction, as Enlil, the king or father of the gods, is described as having designated the geographically precise border between the two deities and, thus, their respective societies. We also note that even as early as during the third millennium BC those boundaries are not solely determined by geographically natural frontiers such as mountains or rivers, but may be borders designated with precision by, in this example, boundary-stones. ${ }^{1}$

The evident corollary conveyed in this inscription of the distinction of the territorial jurisdictions between the deities Ningirsu and Shara and the societies of their respective city-states, Lagash and Umma, is the existence of the recognition of territorial kinship. One individual is distinguished from another individual depending upon where the individual is from, so a "man from Umma", or an "Ummaean", in contrast to both an individual from Lagash and a "foreigner." The categories "man from Umma", or "Ummaean", and "foreigner" indicate territorial location to have been a reference in self-classification, hence, the existence of territorial kinship that corresponded to a distinction between the deities' jurisdiction. Needless to say, the, for example, "Ummaean" would have also understood himself as being a member of a family; thus, there was a co-mingling of two forms of kinship: descent within a territory, Umma, also, in this example, the deity Shara's territory; and descent within the family. Lest one wrongly posit some kind of historically early, primitive or archaic mentality, by which the distinctiveness of the individual, qua individual, was dissolved into the territorial kinship of being a "Ummaean", numerous Sumerian and Akkadian inscriptions, including collections of laws beginning with those of Ur-Namma (c. $2100 \mathrm{BC}$ ), clearly refer to the autonomous individual, as indicated by the legal categories of the Sumerian lú and the Akkadian awillum, who, as such, possessed authority over himself and his property (see Roth 1997; Von Dassow 2011).

Now, clearly in this inscription concerning the conflict between Lagash and Umma, we are dealing with city-states, although their territorial jurisdictions encompassed other, smaller villages and towns (Kuhrt 1995, p. 43). During the Early Dynastic Period, the populations of these respective city-states were between approximately 20,000 to 30,000 individuals (Steinkeller 2017; Kuhrt 1995, p. 32). The purpose of beginning this examination with an inscription describing the lengthy conflict between the city-states of Lagash and Umma is to introduce the concept of territorial kinship: the self-classificatory category of relation between individuals derived from descent within what is recognized to be a common territory (see Grosby 1995, 2018a). The latter is susceptible to geographical expansion, from the city-state to the nation. The nation is a geographically extensive, yet bounded society of territorial kinship (Grosby 2005, 2018a).

The distinction between city-state and nation is primarily one of geographical extent. The territorial kinship of the nation encompasses individuals from numerous cities who understand themselves not only as residents of those cities but also related to others within the national territory as members (Akkadian, awìlum) of the nation, for example, as a "Babylonian", an "Assyrian", or as a "son of Israel" - to be a "native of the land", as this latter category of legal anthropology appears nineteen times in the Hebrew Bible as a descriptive equivalent or modifier of "Israelite." The national state is the organization of relations of power within the borders of the territorial kinship of the nation.

There is an unavoidable analytical ambiguity or categorial imprecision in the distinction between an expanding city-state, for example, Babylon, the population of which reached several hundred thousand (Van de Meiroop 1997, p. 95), nation, and empire (see Hutchinson 2017, p. 120), as one term,

1 For the distinction between frontier and border, and the relation of each to the formation of the state, see (Grosby 2019). 
for example, "Babylon", could refer to city-state, nation, or empire depending upon the particular historical period. The same multiple references of one term over time applies to "Assyria", Aššur: the city-state; the territory encompassing the triangular area bounded by the cities of Aššur, Arba'il, and Ninevah; and, later beginning with the reign of Adad-nirari II (911-891 BC), when its borders expanded depending upon military advantage, empire. While acknowledging this imprecision, nevertheless analytically significant is the ubiquitous evidence of terms that designate territorial kinship: "a man from Umma"; "son (or people) of $x^{\prime}$, where $\mathrm{x}$ is the designation of a territorially extensive yet bounded society, as in, for example, "people of Hatti", "people of Babylon", "sons (or people) of the land of Assyria", and so forth; or the use of gentilic adjectives, for example, Aššurāyu, "Assyrian man", Aššruayitu, "Assyrian woman." 2 This evidence from throughout much of the history of the ancient Near East is analytically significant because it indicates that territorial kinship in general and nationality in particular cannot be confined to the historical period of "modernity" with its modern state, industrialization, democratic citizenship, and modern means of communication, as wrongly argued by too many fashionable analyses, as if there were not states, markets, long-distant trade, and collections of laws recognizing individuals with control over their property in antiquity (see Grosby 2019). ${ }^{3}$ Territorial kinship and its variations, for example, city-state, nation, and empire, are found throughout all historical periods.

Not only did a city have its god, but so, too, a land of broader geographically scope had its god. For example, the god Aššr was the god of the land of Assyria (Machinist 1993; Postgate 1992); the storm god Taru/Teshub was the god of the land of Hatti (Hoffner 1990); Marduk was the god of Babylon/Babylonia; Kemosh was the god of the land of Moab, and so forth. Any territory, as distinct from merely a geographical area, requires symbolic representation which conveys meaning to that area such that it is a territory, so that there is not merely an individual who dwells within an area, but also where an individual who understands himself or herself and is understood by others to be from that area, thereby recognized as embodying certain territorially bounded characteristics, to be, for example, a Ummaean, Hittite, Assyrian, or Moabite. Those characteristics, while they vary, are often worshipping a particular god or speaking a particular language; they convey the conceptual boundaries of the relation of territorial kinship.

The existence of a bounded area of land infused with meaning, that is, a territory (Grosby 1995), certainly exists for small city-states. Our earliest archaeological evidence of urbanism, from the early Ubaid period (c. 4500 BC) and manifestly so during the Uruk period (c. 35000-3000 BC), reveals not only stamps, seals, and bullae for recording items of property and their amounts in exchange for other items, but also the appearance of monumental architecture of a temple complex, known at the city-state of Uruk as Eanna, "House of Heaven" (Van de Meiroop 1997, chp. 2). That temple complex represented the symbolic center of the city around which its territory and its people were ordered; it conveyed the cultural characteristics or properties-recognition and worship of the god of the city-state- that contributed to the formation of that geographical area into a territory and the individuals in that area into the territorial kinship of a people. Thus, the formation of a city, qua city, has never been merely utilitarian; it has always also been symbolic (Wheatley 1969).

If this is so for the city-state, it is also necessarily even more so for the territorially more extensive nation. An individual may have direct experience of the entire territory of a city-state, so that the familiarity of neighborly co-residence co-exists with, and is expanded by and within that experience to encompass the territory of the city. It is possible for the individual to have a relation of face-to-face encounters with the population of the city-state. Although the individual's direct experience with, and attachment to, both the city and the residents within it will have been increasingly difficult to

2 For the phrases "land/people of Aššur", "land/people of Babylon”, “land/people of Hatti”, and so forth, see (Moran 1992); for the gentilic adjectives Aššurāyu and Ǎšurayītu, see (Parpola 2004) and (Roth 1997, p. 170, II44).

3 For examples of analyses restricting nations to modern times, see (Anderson 1983; Gellner 1983; Breuilly 1982). For analyses supportive of the appearance of nations earlier, see (Hastings 1997; Smith 2004; Roshwald 2006; Hirschi 2012; Gat 2013). 
sustain when the city-state has become a large metropolis of several hundred thousand residents, for example, Babylon, the individual's participation in periodic religious festivals, for example, the Babylonian new year festival ( $a k i t u$ ), at its symbolic center, Esaglia, the temple complex, would have facilitated the existence and stabilization of the relation of the wider territorial kinship of even the metropolis. However, the territory of the nation will generally be too geographically extensive to have been experienced directly by many of its individual inhabitants. Thus, especially crucial for the existence of a national territory will be its symbolic expression which, as such, can be experienced through the cognitive capacities of the individual, that is, by incorporating the image of the nation as a part of the individual's self-understanding. The vehicles for this symbolic expression are developing forms of tradition-language, history and, above all, religion-which contribute to the formation of the boundaries of the nation and its territory, and obviously so when the deity worshipped is the god of the land.

The borders of the geographically more extensive, national territory marked the jurisdiction of the deity. Thus, the location of temples of the god of the land often designated the boundaries of the national territory, for example, as recorded in I Kings 12-29, King Jeroboam built temples at Dan, the northern border of Israel, and at Bethel, the southern border of Israel. And it was evidently believed, before the ascendancy of monotheism, that to leave the native land of one's nation and dwell in another was to worship the god of the land of one's new residence, as seems to be implied by I Samuel 26:17-20.

In the study of religion, the category "monolatry" signifies this conceptual state of affairs, where each nation and its land has a god distinctive to that people and its territory. Thus, with monolatry there is recognition of a multi-polar world of numerous nations in contrast, as Hirschi (2012) observed, to a bi-polar imperial vision, where the world is divided between the civilized inhabitants of the empire and those outside the empire who, as such, are often considered to be barbarians dwelling in an unorganized, chaotic space. In the Hebrew Bible, this multi-polarity of numerous nations was seen to be legitimate, as it was evidently a continuation of creation, "these are the families of Noah's descendants (Shem, Ham, and Japheth), according to their origins (languages and land), by their nations (gôyim)" (Genesis 10:32; see 10:5, 20,31). It appears that the biblical narrative intends for its readers to contrast this proper, heterogeneous multi-polarity of nations, as conveyed in Genesis 10, with the improper, homogeneous empire of Babylon, where there was "one people with one language", as described in Genesis 11. Perhaps the locus classicus of this national, multi-polar monolatry appears in the otherwise monotheistic Hebrew Bible, "When the Most High gave the nations (gôyim) their homes ("inheritances" = respective territories), when he divided humankind ("sons of Adam"), he fixed the borders of the peoples (and their territories) according to the number of gods", as Deuteronomy 32:8 appears in the Dead Sea Scrolls and Septuagint (where the Greek for "nations" is $\varepsilon \theta v \omega v$ ) but not the Masoretic Text.

National misfortune was understood to be a consequence of the national deity's anger toward, or even abandonment of, his land and people. For example, the so-called "Moabite stele" of King Mesha (c. $830 \mathrm{BC}$ ) recounts how Omri, King of Israel, was militarily able to conquer Moab because "Kemosh (the god of Moab) was angry with his land" (Chavalas 2006, p. 313). And the Babylonian "Marduk Prophecy" (Foster 1995, pp. 215-17) describes how over the years the defeats of Babylon by the Hittites, Assyrians, and Elamites took place when the god of Babylon, Marduk, had deserted Babylon for those respective places. The prophecy further describes how Marduk will return to Babylon when a future "King of Babylon (presumably Nebuchadnezzar I, c. 1125-1103 BC) will arise (who) will renew the marvelous temple (of Marduk in Babylon)" ushering in a time of prosperity and peace, when "the harvest of the land will be plentiful, market prices will be favorable, wickedness will be rectified ... (and) brother will have consideration for brother ... (as) there will always be consideration among the people" (Foster 1995, pp. 216-17). However, Marduk did not, in fact, leave Babylon for those places, as his statue was taken from Babylon by those respective, victorious armies, that is, Marduk had been taken captive. 
National prosperity was believed to be dependent upon the appropriate propitiation of the god of the land, as described, for example, in 2 Kings 17:24-27. These verses recount how the individuals from the Assyrian empire who were resettled in (northern) Israel during the reign of the Assyrian King Sargon II (721-705 BC) did not know

the laws of the God of the land, therefore He let lions loose against them which are killing them, for they do not know the laws of the God of the land. Then the King of Assyria gave an order, "send (return) there one of the (Israelite) priests whom you have deported; let him go and dwell there, and let him teach there the laws of the God of the land.

And the re-establishment of the sovereignty of a previously defeated people was represented by the return of the statue of the god of the land where it belonged (see Cogan 1974), as recounted, for example, in the Babylonian "Marduk Prophecy." The return of the statue of the god of the land allowed for the renewal of the native cult, for example, as described in the "Cyrus Cylinder" (Chavalas 2006, pp. 428-29), where Cyrus (c. 538 BC) is portrayed as returning the statues of the foreign gods, previously held in captivity in Babylon, to the sanctuaries in the god's native homelands. ${ }^{4}$ As the "kidnapping" of the deity's statue represented the shattering of the nation's symbolic center, thereby endangering the continuation of its territorial kinship, the return of the statue of the god of the land and the renewal of the native cult represented the re-establishment of its symbolic center.

This monolatrous relation, where a deity is described as having a special regard for a particular people and land, was by no means confined to the history of the ancient Near East. For example, Athena was the god of Athens, and Japan was the home of the sun-god Amaterasu. Hinduism, as Michael Cook (2014, p. 67) observed, "possesses a remarkably sharp territorial sense", as conveyed by the geographical terms "Āryāvarta", the land within which Aryans may dwell, and "Bhāratavarsa" which expands the former to include the southern area of India. Thus, the "conception of (India's) territory was both clear and, once the south had been incorporated, stable", encircled by the sea on the east, west, and south and bounded on the north by the Himalayas, designating "a Hindu Idea of India as a domain of religious activity distinct from the rest of the world" (Cook 2014, pp. 68-69). It is the assertion of a domain (pattern) of religious activity that is distinctive to, or even confined to, a particular territory that is of interest to us as it indicates a convergence between religion and nationality.

This territorial jurisdiction of religion, conveyed explicitly by the monolatrous idea of the god of the land throughout the history of the ancient Near East and the varying expressions of it elsewhere, lends support to the functionalist understanding of religion, however not, as we shall see and which should be obvious, religion per se but religion of the pre-axial age. The functionalist analysis of religion examines how the beliefs and practices of religion contribute to the stability-the coherence and continuity — of a society by affirming and strengthening the attachments of individuals to society (Radcliffe-Brown [1935] 1965; Radcliffe-Brown [1945] 1965). Emile Durkheim's Elementary Forms of Religious Life (Durkheim [1912] 1995) represents the logically consistent formulation of the functionalist perspective by arguing that religion is actually the worship of society by society, as the deity is nothing other than the symbolic representation of society. The clearest examples of the merit of the functionalist perspective are the pre-axial age religions, where the primary deity is a god of the land and its people; thus, the worship of the deity is the worship of the society because the deity is the god of that territorially bounded society. For example, Aššrur, as the god of the land of Aššr, that is, Assyria—where the very term indicates a monolatrous conflation between deity and society—conveyed an Assyrian understanding that the land of Assyria was an extension of, or identical with, the territorial jurisdiction of the deity (Tadmor 1986, p. 205; Machinist 1993, p. 81), thereby facilitating, as we have seen, the territorial kinship of being "Assyrian."

4 For a recent re-evaluation of Cyrus' policies, see (Kuhrt 2007). 


\section{Comparative Framework and Its Complications}

This monolatrous, conceptual conflation between deity, land, and people was disrupted, so argued Karl Jaspers (1953; see also Eisenstadt 1982, 1986, 2003; Bellah 2011), by the axial age revolution: those civilizations that took shape from the sixth century BC to the first centuries of the Christian era-represented by ancient Israelite prophecy, Second Temple Judaism, Greek philosophy, Christianity, Zoroastrianism, Buddhism, and, later, Islam. In contrast to the monolatry of antiquity, characteristic of the axial age was the religious development of a sharp disjunction, or fundamental tension, between the mundane and trans-mundane worlds, with a concomitant emphasis on an other-worldly ethical order, for example, the Christian conception of agape. The existence of this ethical order was a consequence of what Max Weber [1921] (1978) referred to as the rationalization-the doctrinal and moral coherence-within the conceptual sphere of religion that appears with the so-called "religions of the book": scriptures that either contain dogma or set into motion a religion's theological development.

This conceptual heterogeneity that is characteristic of the axial age monotheistic world religions - the reality of this world and that of the other world-stands in contrast to the homologous conception of the pre-axial age religions, where the distinction between these two worlds is either undeveloped or blunted by the monolatrous god of the land and nation. For the monotheistic religions, the vision of what humanity ought to be, represented by heaven or by an eschatology, stands in sharp tension with what humanity is. Thus, contra the functionalist analysis of religion, the monotheistic religions of the axial age bear the potential for being disruptive of the stability of the social and political order by subjecting that order to the expectations of what humanity ought to be or will one day become. For the pre-axial age religions, the image of the proper order of divine justice did not exist in sharp tension with the reality of this world; rather, it was viewed as being inseparable from, hence, a factor contributing to, social cohesion, as was seen above in the discussion of the dependency of national prosperity and sovereignty on the god of the land.

Institutionally, the representatives of the axial age tension between this world and the other word were the religious intellectuals-the prophet, the cleric-organized into a distinct profession. As a separate, organized profession, the clerics became a locus for the development and continued existence of ideas that are potentially disruptive of the stability of the social and political order. In contrast, for the pre-axial age, the religious sphere is inseparable, at least superficially, from the social and political order, the obvious example of which is divine kingship, as in ancient Egypt and Japan.

Obviously, the conceptual development of the axial age revolution poses a decisive challenge to the functionalist analysis of religion, because while religion may and often does contribute to social cohesion by being a bearer of morality, the monotheistic religions of the book may also be disruptive of a social relation, for example, of a nation and its social order of custom, tradition, and law. Thus, Durkheim's analysis is actually applicable not to religion per se, but only to a subset of religious experience, specifically the pre-axial age religions. However, as well shall see, even for the pre-axial age religions, complications arise that qualify the merit of the functionalist analysis of even those religions. We will briefly postpone further discussion of the limitations of both the functionalist argument of the relation between nationality and religion and the historicist disjunction posited by the contrast between the pre-axial age and the axial age by accepting for now the acknowledged merits of both. Accepting those merits will allow us to formulate a comparative framework for analyzing the relation between religion and nationality. Even so, that framework cannot avoid being over schematic, indicating not only those limitations but also that a different analytical framework is called for.

As we have observed, the convergence between nationality and religion is obvious where there is a monolatrous god of the land and of the people who, as a territorial kinship, are of, that is, native to, the land. Throughout the history of the ancient Near East, this convergence has been conceptually explicit precisely when the jurisdiction of the deity is confined to the national territory; or, if not explicitly confined, there is an explicitly formulated, particular and enduring relation between the deity and a land and its people, for example, in Babylon mythology, the divine Marduk's home, as described in the Enuma Elish, is Babylon. An evidently similar explicitness is found in early Japanese Shintoism, as 
Japan is the home of Amaterasu, and in the Hindu conceptions of Āryāvarta and Bhāratavarsa. The relation between nationality and the monotheistic religions is, as noted above, more complicated.

For the religion of the ancient Israelites and Jews, the relation between nationality and religion is explicitly complex. On the one hand, we find in the Hebrew Bible seemingly monolatrous assertions that the bounded land of Israel (see Numbers 34) is Yahweh's land, as explicitly stated in Joshua 22:19, 2 Kings 18:33, Hosea 9:3, Isaiah 14:2 and 25, Jeremiah 2:7, Jeremiah 16:18, and Ezekiel 36:20. And a particular and enduring relation between Yahweh and the land of Israel is expressed in Deuteronomy 11:11-12,

The land that you are crossing over to occupy is a land of hills and valleys, watered by rain from the sky, a land that Yahweh your God looks after. The eyes of Yahweh your God are always on it, from the beginning of the year to the end of the year.

However, on the other hand, possession of Yahweh's land was dependent upon the Israelites living a life worthy of occupying that land by obeying Yahweh's commandments-a condition characteristic of the axial age distinction between what life ought to be and the way it is. If the Israelites abandoned Yahweh's laws, both the "sons of Israel" and the land of Israel (note the terminological conflation, conveyed by the term "Israel" referring to both people and land, characteristic of the territorial kinship of nationality) would become defiled, the result of which would be that the "land will vomit you out" (Leviticus 18:24-30). Moreover and signifying the complication posed by monotheism for nationality, the very uniqueness of Israel before the one, monotheistic God, is called into question in, for example, the magnificent formulations of Amos 9:7,

To me, O Israelites, you are just like the Ethiopians, declares Yahweh. True, I brought Israel up from the land of Egypt, but also the Philistines from Caphtor and the Aramaeans from Kir.

This complexity of the Hebrew Bible's formulation of the relation between nationality and religion is captured succinctly by the tension-filled juxtaposition of universal monotheism with monolatry in Deuteronomy 10:14-16 (see also Exodus 19:5-6).

Even though heaven and the heaven of heavens belong to Yahweh your God, the earth with all that is in it, yet Yahweh set his heart in love in your ancestors alone and chose you, their descendants after them, out of all of the peoples, as it is today.

The complexity of the conceptual tension is explicit: Yahweh, as the one, true God whose jurisdiction is the entire world, has, despite this universal jurisdiction, an enduringly narrowed focus on a particular people and land.

The religion of the ancient Israelites and Judaism represent a conceptually rich combination of pre-axial age monolatry and axial age monotheism that over time developed further in different ways, for example: the Rabbinic, universal conception of the Noahides, where anyone, irrespective of nationality, who is faithful to the seven laws of the covenant between Yahweh and Noah will achieve future salvation (see Babylonian Talmud Sanhedrin 56-59); or the Christian attempt to eliminate altogether the tension-filled combination of monotheism and nationality. The characterization "combination of" is to be preferred to "transition between", as the latter term may imply an unequivocal, progressive development. The latter, despite the rationalization in the development of religion from the ritualistic mythology of monolatry to the legal and ethical doctrines of monotheism, is, as we shall observe, unwarranted because of the de facto continuing existence of a kind of monolatry within the monotheistic civilizations and modern world.

From monolatry and the complex combination of monolatry and monotheism in the religion of ancient Israel and Judaism, we now turn to monotheism. The logic of the monotheistic religions is explicitly universal; for, as there is only one god, his jurisdiction is (or should be!) the entire world. Thus, at least doctrinally (or scripturally), monotheism is indifferent to, or even stands in opposition to, the territory and territorial kinship of nationality. For example, the ultimate, true home for a 
Christian is not a national homeland, so not the Jerusalem of the land of Israel, but instead a "heavenly Jerusalem", as stated in Galatians 4:26 (see also Hebrews 11:16, 12:22, Revelations 21). The distinction that matters for monotheism is not between one territory and territorial kinship from another, but between the faithful and the unfaithful. Numerous quotations from the New Testament confirm the rejection of territorial kinship in favor of a territorially indifferent, hence, universal community of the faithful, for example and most famously, Romans 10:12,

For there is no distinction between Jew and Greek; the same Lord is Lord of all and is generous to all who call on (believe in) him. For everyone who calls on the name of the Lord shall be saved" (see also Galatians 3:28, Colossians 3:11).

And not only in scripture but also later in the Catholic Church's Corpus iuris canonici (Canon Law) is this divergence between nationality and universal monotheism explicitly affirmed, as the jurisdiction of the Church's law was applicable to all Christians irrespective of their nationality (Helmholz 1996, pp. 1-5, 33-36). Similarly, for Islam, the Ummah is the territorially indifferent community of believers, as appears to be asserted in the Qur'an (23:51-52, 2:213) and subsequently manifestly so. Many of the consequences of this explicit, scripturally asserted monotheism are so well known that I only allude to them in passing: the monotheistic religions are missionary; they travel from one area to another; and anyone, irrespective of their origins, can convert to them by these acknowledging their respective, doctrinal truth. ${ }^{5}$

Once one puts aside the fashionable, functionalist understanding of the attachments constitutive of nationality as religion, or categories that obscure the tension between nationality and religion, such as "civil religion", the historical expressions of the tension between nationality and monotheism are easily recognized. Perhaps the most obvious is the Investiture Controversy at the end of the eleventh and the beginning of the twelfth centuries CE. After the reforms of Pope Gregory VII, the Christian Church demanded its autonomy in affairs understood by the Church to be solely those of the Church, that is, "spiritual affairs" (Berman 1983). Shortly thereafter, from 1162 to 1170, there arose the conflict between the English King Henry II and the Archbishop of Canterbury Thomas Beckett, later portrayed by T.S. Eliot in his 1935 play Murder in the Cathedral. And, as is well known, the independence of the Church from the national state was reaffirmed by Thomas More (d. 1535) in his conflict with the English King Henry VIII. The opposition of Becket and More in England or, especially but not only in France, the Ultramontanism of the first Vatican Council, for example, the assertion, in Pastor aeternus (1870), of the primacy of the Pope, should not be understood to represent merely the independence of the Church from the national state. It was that; but it was more. It represents the defense of the Church as a catholic, that is, universal institution.

Indifference or opposition to nationality is also found in the Protestant tradition, for example, among the Mennonites, Anabaptists, the Puritan Roger Williams, and in the writings of Karl Karl Barth (1961, pp. 285-323). After all, Christians have recognized, in Augustine's formulation, "two cities", of God and of man. The national state receives only a qualified support- the extent to which the state secures earthly peace - as both the nation and national state are subject to the judgment of the Church, specifically, its universal recognition that all human beings are the children of God (see Grosby 2016).

There are, however, obvious complications to this schematic, comparative framework ranging from the monolatrous convergence of religion and nationality to the monotheist indifference or opposition to nationality, because there are ubiquitous examples of convergence between all of the monotheistic religions and the territorial kinship of numerous nations. The crucial problem before us has already been raised: do these convergences between monotheism and nationality represent a re-emergence of monolatry? As these convergences between nationality and monotheism run counter to the doctrinal indifference, or even opposition, to territorial kinship that appears in the respective scriptures of

5 The classic examination of conversion remains (Nock 1933). 
the monotheistic religions and their respective theological developments, we may characterize the convergences as "de facto", "implicit", or "historically contingent." In contrast, the monolatry of the pre-axial age was explicit, as it did not exist within, or alongside, doctrinal indifference or opposition to territorial kinship.

As noted, convergences between nationality and monotheism are numerous. Most obvious is the convergence arising from the Treaty of Westphalia (1648), legally codifying nationality by insisting upon one religion for a territory and its people. This particular convergence within Christendom was made possible because of the Protestant Reformation's undermining of the independence of the Catholic Church, as a mundane institution, and, above all, its Canon law, as the Protestants rejected the doctrine of the two swords, initially formulated by Pope Gelasius in his letter (494 CE) to the Emperor Anastasius II and subsequently elaborated upon by Pope Boniface VIII in Unam Sanctam (1302 CE), which explicitly recognized two, different and competing mundane institutions (the two swords). Instead of the doctrine of the two swords, Protestants adopted the doctrine of two kingdoms, which required, so the interpretation of Romans 13 and 8, Christian obedience to the national state, as the Christian kingdom was spiritual.

However, the Treaty of Westphalia did not mark the origin of the convergence between nationality and religion in western Christendom. For example, already several centuries earlier the Pope had territorially segregated Poland from the aspirations of the Teutonic Knights. Furthermore, the distinctions of the Council of Constance (1414-1418) between nationes princiales (France, Italy, England, Germany, Spain) and nationes particulares (Poland, Bohemia, Hungary) indicate that the term natio (nation) had come to signify both an ecclesiastical and secular territorial jurisdiction (Hirschi 2012, pp. 81-88).

Various and early examples of activities contributing to the convergence between nationality and monotheism are well known to scholars of religion but too often ignored by scholars of nationalism. One is the translation of scripture into native languages, for example, Cyril's and Methodius' (d. 885) translation of the Bible into Old Church Slavonic and the establishment of a Slavonic liturgy, Wycliff's translation of the Bible into English (c. 1380), Hussite translations of the Bible into Czech and Hungarian (c. 1430), and Luther's translation of the Bible into German (c. 1520). These translations and liturgies in native languages contributed to the convergence between nationality and monotheism by stabilizing the vernacular of a national language and by rendering scripture accessible to the laity. Note that these activities contributing to the formation of nationality were not state-directed. There have been times when the traditions of a monotheistic religion have been important, if not decisive, bearers of nationality in the absence of a national state, for example: the Catholic Church for Poland during the eighteenth and nineteenth centuries; and the Romanian Church which followed the Byzantine rite, under the supervision of the Patriarchate of Constantinople, as a source of unity for the Romanians, who were otherwise divided among the territories of Moldavia, Wallachia, and Transylvania until the formation of the modern Romanian state in 1918.

Of course, activities contributing to convergence between a monotheistic religion and nationality could be and often were state-directed, for example, the translation of the Qur'an into Persian by the tenth century CE, as Persian, albeit in Arabic script, had been declared by the Samanids to be the language of the land of Iran. Another, better known example was the English government's decisions both to have translated scripture from Latin into English and to make more consistent the liturgy in the national vernacular, respectively, the King James Bible (1611) and the Book of Common Prayer. Less well known activities contributing to the formation of nationality were other expressions of the territorial organization of Christianity pre-dating the papal recognition of a Polish territory and the divisions of the Church at the Council of Constance, for example, the English King Edgar's monastic reforms at the end of the tenth century (Banton 1982), where he established forty monasteries throughout England, thereby facilitating the development of a religiously relatively homogeneous territory and population-a development reminiscent of the placement of temples at the borders of a territory as one finds in antiquity. 
Two other developments clearly indicate the convergence of nationality and an otherwise doctrinally universal monotheism. The first is the peculiar phenomenon of national saints, for example, Olaf for Norway, Louis IX for France, Patrick for Ireland, George for England, Sanisław for Poland, and Sava for Serbia. ${ }^{6}$ Here, we observe the transformation of a deceased human into a divine protector, similar to the ancient Greek apotheosis of the hero (see Nock [1944] 1972). These saints were both expressions and protectors of the territory of a particular nation and its people. The peculiarity of a Christian in heaven embodying and protecting a nation is understandable as these figures had been kings and/or military heroes of their respective, developing nations. Thus, their apotheosis accords with the functionalist analytical framework.

The existence of these saints is the medieval anticipation of what explicitly appears organizationally in Eastern Orthodoxy and with the Protestant Reformation: the national church, as in England or Sweden, where religion is also a bearer of national tradition. But the phenomenon of a heavenly protector of a nation within monotheism is manifestly peculiar when no less than Mary, mother of God, is recognized as the divine protector of a nation, specifically, when Mary as the "Queen of Poland" was believed to have putatively saved Poland at the Battle of Częstochowa (Davies 1982, pp. 172, 401). Why should Mary be Polish and not Swedish? Moreover and importantly, here, it is not the individual who is saved from death through eternal life, as is expected in Christian belief (so, for example, I Corinthians 15), but it is the nation as a corporate body that is saved from death.

The second development indicating the convergence of nationality and monotheism is the appearance, especially during the sixteenth through eighteenth centuries, of the "new Israels" in European history. Here, the problem confronting Christendom was how to legitimate nationality within otherwise universal Christianity. To do so, European Christians drew upon the symbolic repertoire available to them, namely, the Israel of the Bible, however, not the "true Israel" of the new Church of their New Testament but the nation of Israel of their Old Testament (Grosby 2011; Smith 2007). By doing so, the conceptual move was made from an implicit convergence between nationality and monotheism, for example, in the Church's de facto territorial administration at the Council of Constance, to a doctrinally justified, hence, explicit, convergence, even though that movement required the retrieval of the image of the nation of ancient Israel in the service of applying that image to different nations of Europe. Needless to say, this adaptive resurrection, if you will, of the image of the nation of ancient Israel of the Old Testament into the life of early modern Europe also revived the tensions between the Old and New Testaments that had been suppressed by the Christian tradition of metaphorical and allegorical interpretation, as found, for example, in the early work of Justin Martyr's Dialogue with Trypho and Irenaeus' Against Heresies. Those tensions continue to haunt Christianity today, namely, the problem of the place for patriotism within the territorially indifferent brotherhood of all believers. Be that as it may, rekindled in the Western, Christian tradition was the idea of a nation being a "chosen people", of national providence-an idea found not only in the American tradition (Goldman 2018) but also in the tradition of the New or Third Rome of Russian orthodoxy as the territory of "Holy Russia' was viewed as inseparable from the orthodox religion (Cherniavsky 1958; Carleton 2016), albeit within a developing imperial context.

It may be that these and other examples of the convergence between universal Christianity and nationality were conceptually possible because of Christianity's doctrinal recognition of two realms: God's and Caesar's, so Matthew 22:21, Mark 12:17, and Luke 20:25. Within the Christian tradition, the earthly realm is accorded the legitimacy to develop in various ways, including, but not necessarily, as nations. The latter possibility garnered support through the appeal to the Old Testament, for example, the "New Israels" of early modern Europe and America, even though the relation, for Christianity, between these two realms was and remains necessarily tension-filled. It seems that phenomena roughly similar to the development of this convergence are to be found outside Christendom, even where

6 The classic work on the saints is (Brown 1982). 
the conceptual arena for "what is Caesar's" or "the city of man" to develop is lacking. Within the Buddhist tradition, despite the indifference to earthly attachments in pursuit of Nirvana, recognition of a distinctive territory developed, of a holy land, that is, Sri Lanka, as described in the fifth century CE Mahāvamsa, which recounts how the island became transformed into a holy territory because of the putative, three visits of the Buddha to Sri Lanka, subsequently marked by Buddhist stupas (shrines). Irrespective of how the Mahāvamsa has been ideologically exploited by Sinhalese nationalists today, it is an example of how an axial age religion has contributed to the formation of a nation, the Sinhalese, Buddhist territorial kinship (in contrast to the Tamil Hindus). Iran is another example, where, in this case, despite the universal Ummah of all believers, Shi'ite Islam, while not confined to Iran, has contributed to the continuation of the long tradition of a distinctive Iranian culture and nation, and assuredly so with, and subsequent to, the adoption of Shi'ism by the Safavids (1502-1736 CE), thereby further distinguishing the Iranians from the Sunni Ottomans.

Now, the problem arises how to evaluate within the monotheistic civilizations developments such as: the institutional distinctions within both the Catholic Church and Eastern Orthodoxy that correspond to national territories, national saints, the "New Israels" throughout European history, and a seemingly national Buddhist Sri Lanka and Iranian Islam. Do we have the re-emergence of a, de facto, monolatry?

The reason for the qualification of the seemingly modern appearance of monolatry as "de facto" or, as referred to earlier, as "implicit" or "historically contingent" is that it appears within the religious tradition of monotheism. As such, the convergence cannot be justified scripturally or doctrinally. Once again, there is an explicit tension between nationality, on the one hand, and Christianity, Islam, and Buddhism, on the other. Nevertheless, as has been observed, there are numerous examples of the convergence between nationality and monotheism, despite the latter's doctrinal universalism, and, therefore, the evident need to characterize that convergence as de facto, implicit, or historically contingent. As noted, Judaism represents an explicit, that is, scriptural and theological, combination. The exception to this implicit or historically contingent convergence within the Christian tradition is when that tradition explicitly appealed to its Old Testament-an appeal that resulted in the "New Israels" of the conceptually paradoxical Christian Hebraism (Grosby 2011).

A schematic, comparative framework of the relation between nationality and religion emerges, ranging from convergence to divergence. The convergence clearly and explicitly appears with pre-axial age monolatry. Next is the complex combination of monolatry and monotheism of the religion of ancient Israel and Judaism. Finally, the convergence between religion and nationality is less likely with the other world, monotheistic religions. However, within the latter, the convergence is more likely within the conceptual heterogeneity of the Christian tradition than with Islam and Buddhism. Although there are differences within the Christian tradition, for example, the caesaropapism of Eastern Orthodoxy, or the doctrines of the two swords and two kingdoms, Christianity conceptually has an arena, viewed as legitimate even if sinful, for the earthly attachments of the territorial kinship of nationality to develop: the city of man. In contrast, for Islam, the Ummah is to be realized in this world, thereby, at least doctrinally, leaving little conceptual space for nationality to develop. For Buddhism, earthly attachments are devalued. Nonetheless, even with the Islamic and Buddhist traditions, de facto monolatrous convergences between nationality and religion are found.

However heuristically useful, even with its qualifying complications, this schematic comparative framework of the relation between nationality and religion may be, historically it is manifestly superficial. In antiquity, there were not only city-states and national states but also empires with universal aspirations, specifically but not only neo-Assyrian and Roman. It seems that for all historical periods, beginning with the Akkadian Sargon (2288-2235 BC), the organization of humanity has gravitated between nationality and empire. In antiquity, the consequences of empire were associated with different religious developments: the expanding territorial jurisdiction of the previously monolatrous, national god; some kind of syncretism; or even, as is clear from the conclusion of the Babylonian Enuma Elish, where Marduk is described as having incorporated the names and attributes of fifty other 
deities, a kind of proto-monotheism. These kinds of complications render any comparative framework superficial, as it is overly abstract. Furthermore, because, for Islam, the Ummah is the community of all believers to be realized in in this world, Islam has historically been conducive to empire. The logic of monotheism, when applied to the realm of politics, is imperial. But Christianity disrupts a consistent application of that logic, as it recognizes two cities, two realms. Thus, Christian monotheism has, throughout its history, been a fertile ground for empire, nationality, and indifference to both. Finally, the de facto monolatry of the monotheism of the axial age period, specifically but not only throughout the history of Christendom-medieval (see Reynolds 1984, pp. 250-331), early modern (see Hirschi 2012), and today-represents an additional, significant complication, if not decisive challenge, to any generalization of historical periodization of the comparative framework.

If we are correct to observe the modern appearance of a kind of monolatry, our understanding of the rationalization of the different spheres of modern life, above all, religious and political, must be qualified. That rationalization certainly cannot be viewed as being unequivocal or homogeneous; for the ideas of either the formal or substantive equality of all human beings, while asserted respectively by the rule of law and monotheism, have been disrupted by that modern monolatry. In light of these many complications to a comparative framework for the relation between nationality and religion, what is called for is a different analytical framework: one that recognizes several perennial orientations of human thought, attachment, and action, for example, religious, kinship, and the legal and economic relations of the market, that, while their historical expressions obviously vary, coalesce in different ways in different times. That there is variation can scarcely be ignored; for otherwise we would not find heuristically useful the distinction between our categories of monolatry and monotheism, or between the different forms of territorial kinship and their political organization-city-state, national state, and empire. And yet, the evidence, for example, the existence of city-states, nations, and empires throughout all historical periods, or the re-emergence of monolatry, provides reasons to be skeptical of unequivocal, historical periodizations. Both religion and various structures of kinship persist, and they come together in ways that significantly complicate any attempt to generalize historically the numerous expressions of their appearance. One must account not only for that persistence, albeit with historical variation, but also the re-emergence or perhaps continuation of monolatry within monotheism, however conceptually paradoxical its appearance may be. Doing so will require clarification of religion as a distinctive category of thought and conduct (see Grosby 2018b).

\section{Religion}

Durkheim, in The Elementary Forms of Religious Life (Durkheim [1912] 1995), made important contributions to how symbols and their relative objectivity, once lifted out of the ebb and flow of life, represent social relations. Nevertheless, two mistakes were made in that work. The first was the incorrect assumption that what he thought was true of Australian totemism, namely, that religion was the worship of society, was characteristic of religion, qua religion. This functionalist assumption was incorrect because, as noted, the central feature of the axial age monotheistic religions is the tension between the reality of this world and the ideal of another world; that is, the axial age religions stand in judgment of mundane relations, including the nation. Thus, while the axial age religions, as bearers of morality, may function as support for the stability of the attachments necessary for a society to exist, they also may be disruptive of those attachments, as is clear with prophecy and the eschatological expectations of all of the monotheistic religions. The second mistake, often ignored or even shared by many scholars, was to view the forms of Australian totemism as being applicable to all of the pre-axial age religions of antiquity. Those historically early religions were not uniform. There were not only differences between them; but, as we shall see, there were also conceptual tensions within them. What both mistakes have in common is an overly simplistic view of religion through an elimination of anything distinctive to it as a category of human thought, attachment, and action.

It is the case that in ancient Egypt and throughout the history of Japan we find divine kinship. The Egyptian pharaoh and the Japanese emperor were considered to be divine. Thus, the existence 
and fate of the distinctive territorial kinship of, respectively, the ancient Egyptians and Japanese, was grounded in the order of the universe, as the representatives of that kinship-respectively, the pharaoh and the emperor-were thought to be divine. Here, there is merit to the functionalist analyses of religion, because the worship of these rulers, since they represent their respective societies, function as the worship of those societies.

In the long history of the ancient Near East, we also find divine kinship. During the reign of Naram-Sin (2254-2218 BC), grandson of Sargon of Akkad, Naram-Sin was described as a god. His deification is conveyed in this inscription (Chavalas 2006, pp. 20-21).

Naram-Sin, the mighty one, king of Akkad: when the four regions of the world revolted against him, because of the love which Ishtar showed him, he was victorious in nine battles in one year... Because he fortified the foundations of his city during this time of distress, (the residents of) his city asked of Ishtar in Eanna, of Enlil in Nippur ... that he be the god of their city, Akkad, and they built his temple within Akkad.

However, there are complications to be found in different accounts of Naram-Sin. These complications should be pondered for the sake of achieving an analytical clarity of pre-axial age religion.

The deification of Naram-Sin was, in fact, unusual for the religion of the ancient Near East, as we generally do not find divine kinship throughout the history of the ancient Near East. It is noteworthy that in the so-called Cutha Legend (Chavalas 2006, pp. 36-40) Naram-Sin is described as transgressing the will of the gods in his desire to go to war with the "raven-faced" people of the mountains, presumably the Gutians.

I summoned the diviners ... I inquired of the great gods [but] the key of the great gods did not permit me to go [to war], nor did a divine communication in my dream ... I said to myself let me ... follow the counsel of my own heart. Let me disregard (the counsel) of the god; let me take responsibility for myself.

We subsequently learn in the Cutha Legend that because of Naram-Sin's disobedience to the divine will, as interpreted by the priests, his troops suffer defeat. Only then does he conclude that he must act with the approval of the gods, that is, when that approval is known through priestly divination-through extispicy and interpretation of dreams. Thus, in the accounts of Naram-Sin and his reign, we find not one but two, different pre-axial age religious conceptions: where Naram-Sin is a god; and where he is not only different from the gods but is also subject to their judgment, indeed, punishment for not following their divine will as interpreted by the priests. While certainly those priests do not form an organizational locus for theological generalization as with the religious intellectuals of the axial age, we nonetheless find throughout the history of the ancient Near East an institutional differentiation between king and priest which, as such, provided the basis for this second religious conception even within the pre-axial age religions. What is the significance of that institutional differentiation?

At this point in our analysis, we must proceed with considerable care. The rationalization of religion which took place with the axial age, as described in the previous section, with its institutional corollary of the emergence of the "clerics" as a distinct profession, is not denied. The clerics of the axial age, monotheistic religions do not examine a sheep's entrails or its liver in order to ascertain the communication from the gods. Nonetheless, also not to be denied is the distinction, found in the pre-axial age religions, between this world and the world of the gods, even if that distinction lacks the heightened tension of the axial age's distinction between the two realms. After all, the gods, qua gods, of the pre-axial age religions dwelled in heaven. Thus, one must not overlook the significance of what appears to have been the corollary of the other-worldly existence of the pre-axial age gods: the institutional differentiation between king and priest found throughout the pre-axial age religions. Only those with special qualifications, the priests, could interpret the will, and, hence, speak on behalf of, the gods.

Recognition of the other-worldly existence of the gods of the pre-axial age religions was not merely or primarily a result of their symbolic representation of the social relations constitutive of 
their respective societies, as Durkheim and the functionalists seem to have thought. The belief in their other-worldly existence signified much more, as it conveyed an understanding that the fate of the individual and of society was beyond human understanding and control. This was Naram-Sin's lesson, as described in the Cutha Legend. He learned the danger of the hubris in defying the divine, the proper understanding of which was beyond his knowledge. True enough, in contrast to the dogma and its theological development of the axial age religions, the divine of the pre-axial age religions was interpreted by priestly diviners. But that difference between, on the one hand, the coherence of theological doctrine and, on the other, mythological ritual, important though it is, does not mean that we do not find similarities in both pre-axial and axial age religions. It does not mean that we do not find, for example, in the pre-axial age conceptions of a degree of ethical generalization. Recall, for example, the conceptions of a future brotherhood and justice, characteristic of the axial age religions, from the quotation previously cited from the pre-axial age "Marduk Prophecy", when there will be a time when "wickedness will be rectified and brother will have consideration for brother as there will always be consideration among the people."

We may justifiably extend the lesson of Naram-Sin beyond the danger of his arrogance in acting as if he were a god to the recognition that the individual will never be certain of his or her place in the world, he or she will never be at ease and at home in this world. This latter recognition is well attested in the pre-axial age literature of the ancient Near East. It is found, for example, in the so-called "Poem of a Righteous Sufferer" (Foster 1995, pp. 300-13) with its statements, "I wish I knew that these things (reverence, worship, sacrifices) were pleasing to a god", and "I have pondered these things (the changes in human fortune); but I have made no sense of them." And it is found in the so-called "Babylon Theodicy" (Foster 1995, pp. 316-24), with its rhetorical observations, "Can a happy life be a certainty? I wish I knew how that might come about!" and "Divine purpose is as remote as innermost heaven, it is difficult to understand, people cannot understand it." The problems recognized here involve the vicissitudes of life in this world. The axial age response to these vicissitudes is the deliverance from them in heaven or in an eschatologically transformed future. However, it is a response, not a solution. It represents a theological rationalization in the face of what would otherwise be the seemingly meaningless course of human events; but one based on an assumption, namely, that sorrow and death may be defeated through the belief in an other-worldly or future existence for the individual.

What is important here for our analysis of religion is that the realistic recognitions of both the limitation of human knowledge and the inability of the individual to feel at ease are to be found in the pre-axial age, even if not formulated in scriptures; they are central to all religions, qua religion. The category of religion-for both the pre-axial and axial ages-represents the configuration of thought, variously developed, and conduct in response to the problem of the ordeal of human consciousness about the mystery of the universe, specifically, whether or not there is meaning to its order, and the place of both the individual and his or her society within it. It is the categorial distinctiveness of that response, although variable, for example, monolatry and monotheism, that accounts for why religion is an independent factor in a comparative analysis of its relation to another, different orientation: the significance human consciousness accords to the generation and transmission of life, as represented by different forms of kinship, including the territorial kinship of the nation.

Here, now, is the pressing theoretical problem, namely, the distinctiveness of the orientation of the human mind that we designate by the term "religion." As noted, that distinctiveness is suggested by: one, the historically perennial and ubiquitous institutional differentiation between priest and king; and two, that the deities of the pre-axial age religions, while some may be associated with natural phenomena, dwell in heaven, that is, beyond human existence, understanding, and control, even though attempts, through both ritual and ethical behavior, are made to propitiate them. The character of religion - the positing of an other-worldly realm with an evidently attendant institutional differentiation-indicates that it is a distinctive orientation of human consciousness, that is, it is not derivative of another orientation. It is a response to the distinctive problems of the lack of human knowledge about one's place and the place of one's society in the universe. 
We are with good reason accustomed to concentrate our attention on the differences between pre-axial age and axial age religions, between polytheism, on the one hand, and monotheism, on the other. Irrespective of the obvious merit of recognizing those differences, we ought to pay more attention to what those historically different religions have in common so that we are better able to ascertain both the distinctiveness of the religious orientation in contrast to the other orientations of the human mind, and the variable contours of the relation of one orientation to another, specifically, religion and nationality.

Recall that we face the conundrum of the re-appearance or perhaps continuation of monolatry within monotheism, hence, a de facto or implicit monolatry. Is the answer to this conundrum that the significance accorded to the relations arising from the generation and transmission of life, that is, different forms of kinship, has been frustrated by a rigorously consistent monotheism? Is it because of the persistence of that significance that monotheism has had to accommodate itself to kinship, whether manifested through the family or the nation? And is monolatry an example of that accommodation, as these different orientations cohere into a never uniform unity?

\section{Conclusions}

Central to all religious belief is the recognition of a realm which, although beyond human experience and comprehension, has bearing on human existence. Although there exist significant differences about how that realm is understood, for example, the Christian assertion of a divine agape (so, 1 John $4: 8,16$ ) in contrast to the seemingly incomprehensible fate of the pre-axial age religions, and about how one accesses that realm, for example, through the ethical or righteous conduct of the axial age religions in contrast to the sacrifice and divination of the pre-axial age, all religions posit this realm. What does recognition of this other-worldly realm indicate about the religious orientation of the human mind?

Whatever may be the nature of a primary psychic consciousness, whether developmentally or as a sub-stratum, the human mind, qua human, is open to the world; thus, being for oneself is never only that; for it is always being in the world. This openness to the world, this potential both to create and to be shaped by cultural achievements, finds expression not in a uniform direction or single purpose but in a number of distinct orientations, of which religion is one among several. It appears that these distinct orientations, the existence of which is expressed by historically persistent institutional differentiation of priest, king, judge, and merchant, arise from, and relations are formed in response to, correspondingly distinct problems encountered by and in life. One problem is the determination of the place of the life of the individual and his or her society within the world and universe-a determination that unavoidably involves an evaluation of life itself. This latter determination and evaluation are the concerns of religion. That there is variability in that determination and evaluation is obvious, for example, the grounding of one's society in the order of the universe as conveyed by the quasi-monolatrous Deuteronomy 32:8 in contrast to the universal equality and possible salvation of all individuals as proclaimed in Galatians 3:28 and Romans 10:12. A different problem is not the evaluation of life in the universe but the importance of the propagation and transmission of life itself, the response to which is kinship in all its varying forms, ranging from the family to the territorial kinship of the nation. The etymology of the term nation from the Latin noun natio and the verb nasci, "to be born from", reveals this preoccupation with traceable lines of descent, albeit, for the nation, not within the family but within a territory. A third problem is the order of life, the response to which is law and the state.

Each of the different responses to the respectively different problems of life-the propagation and transmission of life, the evaluation of life within the universe, and the ordering of life-achieves over time a distinctive tradition sustained in various ways, above all, through corresponding institutions, respectively, the family, clan, or nation; the cult, church, and priesthood; and legal codes, courts, market exchanges, and the state. The coming together of the traditions of these different orientations into a unity is what is meant when we use the term "culture." However, that unity is never uniform. There 
are always tensions, sometimes muted and sometimes acute, among these different traditions: for example, between nationality and religion; or between nationality or religion, on the one hand, and the efficient exchange of goods and services in a competitive market-place, on the other; or between the equality before the rule of law and the preferences accorded to different forms of kinship, and so forth. Moreover, there are tensions within each of the distinctive traditions of the respectively distinctive responses to the different problems of life, for example, the tension between formal and substantive justice in the legal ordering of life.

While I have once again formulated a framework for the relation between nationality and religion, this framework is confronted by, indeed, sometimes overwhelmed by, numerous complications arising from the tensions both between the different responses to the problems of life and within each of them. An example of the latter tension within the tradition of the religious orientation was the above recourse to a modification of the earlier characterization to describe Deuteronomy 32:8, from the previous "monolatrous" to now "quasi-monolatrous".

When the Most High (Elyon) gave the nations their homes, when he divided humankind, he fixed the borders of the peoples according to the number of gods.

While, according to this verse, each nation has its own god, the problem of, or the tension within, this otherwise monolatrous formulation is how are we to understand the place of the "Most High", Elyon, in this religious conception of the world? Does Elyon's existence qualify the authority and jurisdiction of the other national gods? Are the latter subordinated to him? And, if so, what is the extent of that subordination? Finally, what is the relation between Elyon and Yahweh? Are they the same god or different gods? The following verse, Deuteronomy 32:9, only increases the pressing relevance of these questions, "for Yahweh's portion is His people, Jacob His own allotment."

Whether or not Yahweh is Elyon here, throughout the historically earlier pre-axial age religions of the ancient Near East, there were, in fact, other, usually older gods who co-existed with, and sometimes exercised authority over, younger gods, for example, in ancient Ugarit, the older El and the younger Baal, or in ancient Babylon, the older Anu and the younger Marduk, and in ancient Israel, perhaps the older El/Elyon and the younger Yahweh. This co-existence, however interpreted, for example, the earlier generation of the gods representing natural phenomena while the younger, political, and however conceptually undeveloped, represents tensions within the pre-axial age religions.

One conclusion to which these questions lead us is that our analytical categories, for example, monolatry, monotheism, nation, empire, are abstractions that, as such, often obscure the conceptual tensions within each of them. This conclusion is, of course, a commonplace. The closer we examine each category and its application to a particular historical moment, we encounter complications to those categories, for example, the apparent need to characterize Deuteronomy 32:8 as "quasi-monolatrous", or the existence of national saints within otherwise monotheistic Christendom, or the national monotheism of Iranian Islam and Sinhalese Buddhism. The important point here is not the conclusion that our analytical categories often obscure numerous complications, but whether or not there are recurring patterns, however variable, to these complications, above all, in the relation between these categories, specifically, nationality and religion.

It seems that one reason for these many complications to our categories is the conceptual tensions existing not merely within each of them but also between them, when the different responses to the problems posed by life come together into a never uniform unity, into a national or civilizational culture. One orientation exerts an influence on another, for example, the territorial kinship of the nation on monotheism. This, too, may be a commonplace. But it is a commonplace that assumes the logically autonomous orientations of the human mind, of which religion is one, and the territorial kinship of the nation is another, in response to different problems of life.

Funding: This research received no external funding.

Conflicts of Interest: The author declares no conflict of interest. 


\section{References}

Anderson, Benedict. 1983. Imagined Communities. London: Verso.

Banton, Nicholas. 1982. Monastic Reforms and the unification of tenth-century England. In Religion and National Identity. Edited by Stuart Mews. Oxford: Basil Blackwell, pp. 71-86.

Barth, Karl. 1961. Church Dogmatics. Edinburgh: T\&T Clark, vol. III, Part Four.

Bellah, Robert. 2011. Religion in Human Evolution: From Paleolithic to the Axial Age. Cambridge: Cambridge University Press.

Berman, Harold. 1983. Law and Revolution. Cambridge: Harvard University Press.

Breuilly, John. 1982. Nationalism and the State. Chicago: The University of Chicago Press.

Brown, Peter. 1982. The Cult of the Saints: Its Rise and Function in Latin Christianity. Chicago: The University of Chicago Press.

Carleton, Gregory. 2016. A Russia Born in War. In The Roots of Nationalism. Edited by Lotte Jensen. Amsterdam: Amsterdam University Press, pp. 153-66.

Chavalas, Mark. 2006. The Ancient Near East: Historical Sources in Translation. Malden: Blackwell.

Cherniavsky, Michael. 1958. Holy Russia: A Study of the History of an Idea. American Historical Review 63: 617-37. [CrossRef]

Cogan, Mordechai. 1974. Imperialism and Religion: Assyria, Judah and Israel in the Eighth and Seventh Centuries BCE. Atlanta: Society of Biblical Literature.

Cook, Michael. 2014. Ancient Religions, Modern Politics: The Islamic Case in Comparative Perspective. Princeton: Princeton University Press.

Cooper, Jerrold. 1986. Presargonic Inscriptions. New Haven: American Oriental Society.

Davies, Norman. 1982. God's Playground: A History of Poland. New York: Columbia University Press.

Durkheim, Emile. 1995. The Elementary Forms of Religious Life. New York: The Free Press. First published 1912.

Eisenstadt, Shmuel Noah. 1982. The Axial Age: The Emergence of Transcendental Visions and the Rise of the Clerics. European Journal of Sociology 23: 294-314. [CrossRef]

Eisenstadt, Shmuel Noah, ed. 1986. The Origins and Diversity of Axial Age Civilizations. Albany: State University of New York Press.

Eisenstadt, Shmuel Noah. 2003. Comparative Civilizations and Multiple Modernities. Leiden: Brill.

Foster, Benjamin. 1995. From Distant Days: Myths, Tales, and Poetry of Ancient Mesopotamia. Bethesda: CDL Press.

Gat, Azar. 2013. Nations: The Long History and Deep Roots of Political Ethnicity and Nationalism. Cambridge: Cambridge University Press.

Gellner, Ernst. 1983. Nations and Nationalism. Oxford: Blackwell.

Goldman, Samuel. 2018. God's Country: Christian Zionism in America. Philadelphia: University of Pennsylvania Press.

Grosby, Steven. 1995. Territoriality: the transcendental, primordial feature of modern societies. Nations and Nationalism 1: 143-62. [CrossRef]

Grosby, Steven. 2001. Nationality and Religion. In Understanding Nationalism. Edited by Montserrat Guibernau and John Hutchinson. Cambridge: Polity Press, pp. 97-119.

Grosby, Steven. 2002. Biblical Ideas of Nationality: Ancient and Modern. Winona Lake: Eisenbrauns.

Grosby, Steven. 2005. Nationalism: A Very Short Introduction. Oxford: Oxford University Press.

Grosby, Steven. 2011. Hebraism: The Third Culture. In Judaic Sources $\mathcal{E}$ Western Thought. Edited by Jonathan Jacobs. Oxford: Oxford University Press, pp. 73-96.

Grosby, Steven. 2016. National Identity, Nationalism, and the Catholic Church. In Oxford Handbooks Online. Available online: https://www.oxfordhandbooks.com/view/10.1093/oxfordhb/9780199935420.001. 0001/oxfordhb-9780199935420-e-61 (accessed on 19 July 2019).

Grosby, Steven. 2018a. Time, Kinship, and the Nation. Genealogy 2: 1-17. [CrossRef]

Grosby, Steven. 2018b. Nationality and Religion. Nations and Nationalism 24: 258-70. [CrossRef]

Grosby, Steven. 2019. Borders and States. In A Companion to the Ancient Near East, 2nd ed. Edited by Daniel Snell. Malden: Wiley-Blackwell, forthcoming.

Hastings, Adrian. 1997. The Construction of Nationhood: Ethnicity, Religion and Nationalism. Cambridge: Cambridge University Press.

Helmholz, Richard. 1996. The Spirit of Classical Canon Law. Athens: University of Georgia Press.

Hirschi, Caspar. 2012. The Origins of Nationalism. Cambridge: Cambridge University Press. 
Hoffner, Harry. 1990. Hittite Myths. Atlanta: Scholars Press.

Hutchinson, John. 2017. Nationalism and War. Oxford: Oxford University Press.

Jaspers, Karl. 1953. The Origin and Goal of History. New Haven: Yale University Press.

Kuhrt, Ámelie. 1995. The Ancient Near East c. 3000-330 BC. London: Routledge.

Kuhrt, Ámelie. 2007. Cyrus the Great of Persia: Images and Realities. In Representations of Political Power: Case Histories from Times of Change and Dissolving Order in the Ancient Near East. Edited by Marlies Heinz and Marian Feldman. Winona Lake: Eisenbrauns, pp. 169-91.

Machinist, Peter. 1993. Assyrians on Assyria in the First Millennium B.C. In Anfänge Politischen Denkens in der Antike: Die nahöstlichen Kulturen und die Griechen. Edited by Kurt A. Raaflaub. Munich: R. Oldenbourg, pp. 77-104.

Moran, William L. 1992. The Amarna Letters. Baltimore: The Johns Hopkins University Press.

Nock, Arthur Darby. 1972. The Cult of the Heroes. In Essays on Religion and the Ancient World. Edited by Zeph Stewart. Oxford: Clarendon Press, pp. 575-602. First published 1944.

Nock, Arthur Darby. 1933. Conversion. Oxford: Clarendon Press.

Parpola, Simo. 2004. National and Ethnic Identity in the Neo-Assyrian Empire and Assyrian Identity in Post-Empire Times. Journal of Assyrian Studies 18: 5-22.

Postgate, J. Nicholas. 1992. The Land of Assur and the Yoke of Assur. World Archaeology 23: 247-63. [CrossRef]

Radcliffe-Brown, Alfred Reginald. 1965. On the Concept of Function in Social Science. In Structure and Function in Primitive Society. New York: The Free Press. First published 1935.

Radcliffe-Brown, Alfred Reginald. 1965. Religion and Society. In Structure and Function in Primitive Society. New York: The Free Press. First published 1945.

Reynolds, Susan. 1984. Kingdoms and Communities in Western Europe, 900-1300. Oxford: Clarendon Press.

Roshwald, Aviel. 2006. The Endurance of Nationalism: Ancient Roots and Modern Dilemmas. Cambridge: Cambridge University.

Roth, Martha. 1997. Law Collections from Mesopotamia and Asia Minor. Atlanta: Scholars Press.

Smith, Anthony D. 2004. The Antiquity of Nations. Cambridge: Polity Press.

Smith, Anthony D. 2007. Nation and Covenant: The contribution of ancient Israel to modern nationalism. Elie Kedourie Memorial Lecture. Proceedings of the British Academy 151: 213-55.

Steinkeller, Piotr. 2017. An Estimate of the Population of the City of Umma in Ur III Times. In At the Dawn of History: Ancient Near Eastern Studies in Honour of J.N. Postgate. Edited by Yağmur Heffron, Adam Stone and Martin Worthington. Winona Lake: Eisenbrauns, pp. 535-66.

Tadmor, Hayim. 1986. Monarchy and Elite in Assyria and Babylonia: The Question of Royal Accountability. In The Origins and Diversity of Axial Age Civilizations. Edited by Shmuel N. Eisenstadt. Albany: State University of New York Press, pp. 203-24.

Van de Meiroop, Marc. 1997. The Ancient Mesopotamian City. Oxford: Oxford University Press.

Von Dassow, Eva. 2011. Freedom in Ancient Near Eastern Societies. In The Oxford Handbook of Cuneiform Culture. Edited by Karen Radner and Eleanor Robson. Oxford: Oxford University Press, pp. 205-28.

Weber, Max. 1978. Economy and Society. Berkeley: University of California Press. First published 1921. Wheatley, Paul. 1969. City as Symbol. London: H.K. Lewis.

(C) 2019 by the author. Licensee MDPI, Basel, Switzerland. This article is an open access article distributed under the terms and conditions of the Creative Commons Attribution (CC BY) license (http://creativecommons.org/licenses/by/4.0/). 